\title{
Nutrient condition and chironomid assemblages in Kolkata, India: assessment for biomonitoring and ecological management
}

\author{
Soumi NANDI, ${ }^{1}$ Gautam ADITYA, ${ }^{1,2}$ Goutam K. SAHA ${ }^{1}$ \\ ${ }^{1}$ Department of Zoology, University of Calcutta, Kolkata, India; ${ }^{2}$ Department of Zoology, University of Burdwan, Golapbag, India \\ *Corresponding author: gkszoo@rediffmail.com
}

\begin{abstract}
Chironomid species in water bodies are useful indicators of the nutrient and environmental states. The relative abundance of chironomids and nutrients like organic carbon $(\mathrm{C})$, potassium ions $\left(\mathrm{K}^{+}\right)$, nitrate $\left(\mathrm{NO}_{3}^{-}\right)$, and phosphate $\left(\mathrm{PO}_{4}^{2-}\right)$ of the water bodies were analyzed using numerical techniques such as Principal Component Analysis (PCA), Canonical Correspondence Analysis (CCA) and Cluster Analysis (CA) to justify the use of chironomids in environmental biomonitoring. The data analyses of 90 samples from eight different ponds Kolkata, India, revealed the presence of 12 chironomid species in different relative densities. The chironomid immature numbers per unit area was found to be positively correlated with $\mathrm{C}$ and $\mathrm{PO}_{4}^{2^{-}}$, while no definite significant correlation was observed for $\mathrm{K}^{+}$or $\mathrm{NO}_{3}{ }^{-}$. The PCA yielded three components that could explain $>63 \%$ of variation of the observed data. In terms of factor loadings, $p H, K^{+}$, $\mathrm{NO}_{3}^{-}$and $\mathrm{PO}_{4}^{22^{-}}$contributed to the first factor, while $\mathrm{C}$, water temperature and dissolved $\mathrm{O}_{2}$ contributed to the second factor. The CCA showed distribution of the chironomid species to differ against the variance of water quality parameters. The first canonical axis $\left(\lambda_{1}=0.156 ; F=5.126 ; P<0.05\right)$ explained $69 \%$ of species - environment relationship. The abundance of three species of chironomid midges, Chironomus striatipennis, C. circumdatus and Kiefferulus calligaster was prominent in all the water bodies. Cluster analysis showed that these species were highly correlated in their abundance contrast to remaining species. The results indicate that the water quality parameters influence the chironomid species assemblages to a considerable extent. This is supportive of the use of chironomid midges in biomonitoring for ecological management of urban water bodies of Kolkata, India and similar geographical areas.
\end{abstract}

Key words: biomonitoring, ecological management, chironomid midges, nutrient, urban ponds.

Received: January 2012. Accepted: June 2012.

\section{INTRODUCTION}

The immature stages of the chironomid midges (Chironomidae: Diptera) are abundant in wide range of lentic and lotic habitats. The larval stages of majority of chironomid species are benthic and utilize detritus, suspended materials and sediment as resources for nest building and food (Ashe et al., 1987; Ashe and Cranston, 1990). It has been noted that the abundance and growth of chironomid larvae is positively correlated with the sediment quality and environmental conditions (DeHaas et $a l$., 2006). The collection of suspended particulate materials by the larval chironomids results in bioturbation of the nutrients in the aquatic habitats that facilitate nutrient availability to the autotrophs and enhance productivity of the habitats (Biswas et al., 2009). The trophic position of the chironomid in aquatic food web links the grazing and detritus based food chains since many predatory aquatic insects (Aditya et al., 2006; Aditya and Saha, 2006; Saha et al., 2009, 2010) and fishes (Manna et al., 2008, 2011) prey upon chironomid larvae. These features along with the ability to tolerate wide range of environmental conditions (Rossaro, 1991; Mousavi, 2002; Luoto, 2011), qualify larval chironomid as suitable organism that can indicate the various dimensions of the ecological conditions of the habitats.
It is evident from several studies on the streams and lakes that the chironomid diversity can be used as key indicator for local scale fluctuations of ecological conditions (Bazzanti et al., 1997; Tellioglu and Kara, 2009) and biotic integrity (Rossaro et al., 2007; Haase and Nolte, 2008). Several biological and physico-chemical features have been correlated with chironomid abundance evident from the studies of lakes and rivers around the world, particularly in temperate zones (Lobinske et al., 1996; Ali et al., 2002, 2003; Stevens et al., 2006; Luoto, 2011). The extent of deformities of chironomid larvae are correlated with the pollution level of the aquatic environment and therefore chironomid are useful indicators of pollution (Bhattacharyay et al., 2005, 2006; Carew et al., 2007). Such utilities of chironomid larvae have been further strengthened by the findings that the chironomid larvae act as indicators of the antibiotic resistant bacteria in the environment (Basu et al., $2010 \mathrm{a}, \mathrm{b}$ ) and trophic conditions of temperate lakes (Luoto, 2011). Chironomid midges are thus model organisms for monitoring the environmental conditions of the freshwater environments (Saether, 1979; Rosenberg, 1992; Luoto, 2011). Based on these, in the present study an attempt has been made to judge the relation between chironomid abundance and the nutrient conditions of the urban ponds. An estimated 4147 chironomid 
species have been described worldwide, of which 359 species under 105 genera represents Oriental realm (Ferrington, 2008). While taxonomic details of chironomid midges are being done vastly (Guha et al., 1980; Chaudhuri et al., 1983, 1988, 1992; Chaudhuri and Ghosh, 1986; Chaudhuri and Chattopadhyay, 1990; Mazumdar et al., 2000) and continued till now, little effort has been made to correlate the environmental variables with chironomid abundance in urban areas like Kolkata, India. In this context, the present study is expected to highlight the chironomid diversity in urban ponds in Kolkata, India, in relation to the major nutrients. Following the studies on the predatory potential of different heteropteran bugs, coleopteran beetles, odonate larvae and fishes in these aquatic bodies (Aditya and Saha, 2006; Manna et al., 2008, 2011; Saha et al., 2009, 2010), it is pertinent to record the diversity of chironomids that sustain these predatory insects (Ormerod et al., 2009; Cushman et al., 2010). A correlation of the diversity of chironomid midges with the nutrient conditions will substantiate the hypothesis related to their utility as indicators of the aquatic bodies of this region (Basu et al., 2010 a,b). This would enable to frame strategies for ecological restoration and management of the urban ponds and substantiate the use of chironomid larvae in biological monitoring of aquatic system.

\section{METHODS}

\section{Study site}

The study was carried out on 8 major water bodies named as EI, EII, SI, SII, NI, NII, WI and WII located in and around Kolkata metropolis, India. The ponds are named based on their location in the east (E) (Tiljala, 2231'49.21" N; 88²3'40.72” E), west (W) (Ichapur, Howrah, 2235'18.92" N; 88¹8'44.09” E), north (N) (Baranagar, 22 $2^{\circ} 8^{\prime} 25.75^{\prime \prime} \mathrm{N} ; 8^{\circ} 22^{\prime} 19.47^{\prime \prime} \mathrm{E}$ ) and south (S) (Garia, 2228’34.17' N; 88 23'08.63” E), with reference to Ballygunge Science College campus, Kolkata, India, as center $\left(22^{\circ} 35^{\prime} 18.92^{\prime \prime} \mathrm{N}\right.$; 88 $\left.17^{\circ} 54.99^{\prime \prime} \mathrm{E}\right)$. The distance of the water bodies in the East, West, North and South are respectively are $4.7 \mathrm{~km}, 14.7 \mathrm{~km}, 14.4 \mathrm{~km}$ and
$8.7 \mathrm{~km}$ from the central location. These water bodies represented model urban ponds of Kolkata, where anthropogenic interference was customary, without commercial fishery. These natural ponds were sparsely vegetated with the floating weeds Wolffia spp., Lemna minor and Pistia stratiotes as dominant vegetation and Eichhornia crassipes in pond NII. As emergent vegetations Ipomoea aquatica, Alternanthera philoxeroides and Jussia repens were noted in ponds WI and WII, with few representatives in a corner of the pond. The sampling was carried out avoiding these vegetations since the dispersion of the vegetated areas were clumped and was not homogenous among the ponds. The average depth of the ponds were 1 meter in the centre and the surface area were between $700 \mathrm{~m}^{2}$ and $1480 \mathrm{~m}^{2}$ (Tab. 1). Data were taken for a minimum of 9 and a maximum of 14 samples from each of these ponds within a 3month period, from June to August 2010. The data were considered for spatial scale analysis assuming climatic conditions were affecting the ponds in a similar way.

\section{Chironomid collection and rearing}

The chironomid immature, mostly larvae and few pupae, were collected from the bottom sediments of the ponds with the help of a sampler made up of plankton net ( $200 \mu \mathrm{m}$ mesh size) attached to a frame $(25 \times 20 \mathrm{~cm}$ area $)$ with a long handle, following Robert et al. (2002). The sampler was dredged along the sediment bottom (12.5-15 $\mathrm{cm}$ corresponding to the depth and $1 \mathrm{~m}^{2}$ surface area of the ponds) to collect the larvae in a measured quadrat and placed in aerated plastic bags and transported to the laboratory for counting, rearing and identification following adult emergence. The larval rearing in the laboratory was carried out in plastic trays $(36 \times 28 \times 8 \mathrm{~cm})$ containing aged tap water and a bottom layer $(1 \mathrm{~cm})$ of autoclaved mud. The cultures were aerated with aquarium air pump (RS348A, RS Electrical, China) and the water was changed every day. Observations were made on the numbers of individual larvae pupating each day following which the pupae were transferred to individual glass vials $(10 \times 60$ $\mathrm{mm}$ ) with $3 \mathrm{~mL}$ of tap water. The vials were marked for

Tab. 1. A brief description of the ponds considered in the present study. The ponds are named according to the location (W - West, E East, $\mathrm{N}-$ North and $\mathrm{S}-$ South).

\begin{tabular}{lcccc}
\hline Place & $\begin{array}{c}\text { Surface area } \\
\left(\mathrm{m}^{2}\right)\end{array}$ & $\begin{array}{c}\text { Depth } \\
(\mathrm{cm} \text { at centre })\end{array}$ & $\begin{array}{c}\text { Depth } \\
\text { littoral }(\mathrm{cm})\end{array}$ & Shape \\
\hline EI & 1201.44 & 110 & $12-22$ & Rectangular \\
EII & 706.00 & 120 & $10-15$ & Oval \\
SI & 1127.42 & 100 & $10-20$ & Rectangular \\
SII & 1409.39 & 120 & $12-22$ & Rectangular \\
NI & 714.17 & 100 & $10-15$ & Rectangular \\
NII & 1115.84 & 110 & $10-20$ & Oval \\
WI & 1482.64 & 110 & $12-25$ & Oval \\
WII & 1207.64 & 100 & $12-20$ & Rectangular \\
\hline
\end{tabular}


further reference and covered with cloth to prevent escape of emerging adults. Following adult eclosion the individuals were identified to the genus level and further identification to the species level was carried out following the micro slide preparation of adults with the help of phenolbalsam technique as used by Chaudhuri and Guha (1987). Identification of the adult chironomid was made following appropriate keys (Pinder, 1978; Cranston et al., 1989, 2012; Epler, 1992, 1995, 2001; Chaudhuri and Ghosh, 1986; Chaudhuri and Chattopadhyay, 1990).

Confirmation of identifications was done from Entomology Laboratory, Department of Zoology, The University of Burdwan, India.

\section{Analysis of water quality parameters}

During the course of collection of chironomid larvae, sediment and water were also collected for analysis of selected physico-chemical parameters and nutrient conditions of the ponds. Parameters as temperature, $\mathrm{pH}$ and dissolved oxygen (DO) of water were measured using a thermometer, a portable calibrated $\mathrm{pH}$ meter $\left(\mathrm{pHep}{ }^{\circledR} \mathrm{pH}\right.$ meter, Hanna Instrument, Mauritius) and $\mathrm{O}_{2}$ kit (Aquamerck, 1.11107.0001), respectively, at each site and each sampling day. Depth of water from where these measurements were taken remained between 12.5 and 15 $\mathrm{cm}$ depth nearer to the bottom sediments of the ponds. The sediments of the ponds were collected using sampler for determination of organic carbon, which was performed according to the standard methods for the examination of water and waste water (APHA, 1995).

To determine the nutrient of the water samples, water were collected from the same depth with BOD bottle for determination of nitrate, phosphate and potassium of the water with the methodology provided by APHA (1995).

\section{Statistical analyses}

A total of 90 samples from the eight ponds were considered for this study. The data on the number of chironomid larvae, physicochemical parameters, and nutrient quality for each sample were subjected to multivariate analyses. A Principal Component Analysis (PCA) was carried out to reduce the redundancy of the data and provide ordination of the variables and their each other relationship.

In the present study eight variables measured in 90 different samples from the eight urban ponds were used as input to yield principal components with Eigen-values of more than 1 , explaining $>70 \%$ of variations in the observed data (Tab. 2) The PCA used here follows the description of Manly (1994) and Legendre and Legendre (1998). Bivariate linear regression equations (Zar, 1999) were constructed to represent the relation between nitrate, phosphate, potassium and organic carbon (nutrient states) with the total chironomid larval abundance.

A Detrended Correspondence Analysis (DCA) was carried out with the matrix of species count in each sample to guide the use of further numerical techniques based on linear or unimodal models. The data were detrended by segments with non linear rescaling and the rare species were down-weighted to measure the length of the compositional gradient. As a rule, unimodal species response model can be used provided the gradient length is greater than twice the standard deviation. Since the analysis

Tab. 2. The values (range, mean $\pm \mathrm{SE}$ ) of the water quality parameters of the ponds considered in the study.

\begin{tabular}{|c|c|c|c|c|c|c|c|}
\hline Pond number & Water quality paran & & & & & & \\
\hline & $\mathrm{N}(\mathrm{E} 1)$ & K (E2) & $\mathrm{P}(\mathrm{E} 3)$ & $\mathrm{C}(\mathrm{E} 4)$ & DO (E5) & $\mathrm{pH}(\mathrm{E} 6)$ & WT (E7) \\
\hline EI & $\begin{array}{c}0.74-6.96 \\
3.14 \pm 0.40\end{array}$ & $\begin{array}{l}19.74-37.47 \\
26.53 \pm 1.57\end{array}$ & $\begin{array}{l}0.29-3.88 \\
1.80 \pm 0.24\end{array}$ & $\begin{array}{l}0.48-3.97 \\
1.48 \pm 0.25\end{array}$ & $\begin{array}{c}2.2-9 \\
5.34 \pm 0.60\end{array}$ & $\begin{array}{c}7-8.3 \\
7.69 \pm 0.12\end{array}$ & $\begin{array}{c}21-40 \\
29.92 \pm 1.60\end{array}$ \\
\hline EII & $\begin{array}{l}1.33-12.14 \\
5.53 \pm 0.85\end{array}$ & $\begin{array}{c}23.21-46.59 \\
31.74 \pm 1.63\end{array}$ & $\begin{array}{c}0.14-5.22 \\
2.06 \pm 0.43\end{array}$ & $\begin{array}{l}0.07-2.11 \\
1.09 \pm 0.14\end{array}$ & $\begin{array}{c}1.4-9.5 \\
5.98 \pm 0.75\end{array}$ & $\begin{array}{c}6.5-8 \\
7.42 \pm 0.11\end{array}$ & $\begin{array}{c}23-36 \\
30.5 \pm 1.09\end{array}$ \\
\hline SI & $\begin{array}{l}1.33-7.56 \\
4.31 \pm 0.41\end{array}$ & $\begin{array}{l}9.05-18.14 \\
14.69 \pm 0.67\end{array}$ & $\begin{array}{l}1.14-3.88 \\
2.31 \pm 0.21\end{array}$ & $\begin{array}{l}0.62-3.41 \\
1.79 \pm 0.26\end{array}$ & $\begin{array}{c}1.2-9.3 \\
6.06 \pm 0.68\end{array}$ & $\begin{array}{c}5.8-8.2 \\
7.54 \pm 0.23\end{array}$ & $\begin{array}{c}25-37 \\
30.21 \pm 0.98\end{array}$ \\
\hline SII & $\begin{array}{c}1.4-6.44 \\
4.28 \pm 0.40\end{array}$ & $\begin{array}{l}9.45-21.13 \\
15.28 \pm 1.03\end{array}$ & $\begin{array}{c}1.11-3.85 \\
2.20 \pm 0.26\end{array}$ & $\begin{array}{c}0.11-2.1 \\
1.28 \pm 0.18\end{array}$ & $\begin{array}{c}3.6-8.2 \\
6.32 \pm 0.35\end{array}$ & $\begin{array}{c}7-8.5 \\
7.67 \pm 0.14\end{array}$ & $\begin{array}{c}25-35 \\
31.33 \pm 1.02\end{array}$ \\
\hline NI & $\begin{array}{c}0.22-1.18 \\
0.61 \pm 0.09\end{array}$ & $\begin{array}{l}1.94-12.10 \\
7.42 \pm 1.02\end{array}$ & $\begin{array}{l}0.14-1.77 \\
0.39 \pm 0.17\end{array}$ & $\begin{array}{c}0.1-2.54 \\
0.80 \pm 0.27\end{array}$ & $\begin{array}{c}2.7-6.8 \\
4.41 \pm 0.44\end{array}$ & $\begin{array}{c}6.5-7.2 \\
6.96 \pm 0.08\end{array}$ & $\begin{array}{c}19-32 \\
26.89 \pm 1.51\end{array}$ \\
\hline NII & $\begin{array}{c}0.88-9.92 \\
2.06 \pm 0.98\end{array}$ & $\begin{array}{l}4.85-18.82 \\
10.97 \pm 1.66\end{array}$ & $\begin{array}{c}0.074-0.59 \\
0.37 \pm 0.05\end{array}$ & $\begin{array}{l}0.29-2.87 \\
1.48 \pm 0.32\end{array}$ & $\begin{array}{c}2.1-5.2 \\
3.03 \pm 0.32\end{array}$ & $\begin{array}{c}6.5-7.5 \\
6.99 \pm 0.11\end{array}$ & $\begin{array}{c}20-38 \\
28.33 \pm 1.73\end{array}$ \\
\hline WI & $\begin{array}{c}2.37-9.4 \\
4.95 \pm 0.88\end{array}$ & $\begin{array}{c}12.12-27.21 \\
19.36 \pm 1.89\end{array}$ & $\begin{array}{c}1-3.59 \\
2.32 \pm 0.34\end{array}$ & $\begin{array}{c}1-3.19 \\
1.95 \pm 0.24\end{array}$ & $\begin{array}{c}2.3-9.3 \\
5.14 \pm 0.69\end{array}$ & $\begin{array}{c}6.5-8.3 \\
7.34 \pm 0.21\end{array}$ & $\begin{array}{c}24-33 \\
29.88 \pm 1.14\end{array}$ \\
\hline WII & $\begin{array}{l}1.85-6.07 \\
4.09 \pm 0.48\end{array}$ & $\begin{array}{c}14.5-26.23 \\
19.72 \pm 1.45\end{array}$ & $\begin{array}{c}0.11-2.85 \\
1.24 \pm 0.25\end{array}$ & $\begin{array}{c}0.21-2.9 \\
1.26 \pm 0.30\end{array}$ & $\begin{array}{c}2.8-9.5 \\
5.32 \pm 0.69\end{array}$ & $\begin{array}{c}6.8-8.4 \\
7.62 \pm 0.17\end{array}$ & $\begin{array}{c}22-35 \\
29.88 \pm 1.47\end{array}$ \\
\hline
\end{tabular}

$N$, nitrate $m g L^{-1}$; P, phosphate $m g L^{-1}$; $C$, organic carbon concentration; $K$, potassium $m g L^{-1}$; DO, dissolved oxygen $m g L^{-1}$; WT, water temperature in ${ }^{\circ} C$. 
yielded such results, further application of CCA (Canonical Correspondence Analysis; ter Braak, 1987; ter Braak and Verdonschot, 1995; ter Braak and Šmilauer, 2002) was used to comment on the species environment relationship. In this method synthetic environmental gradients are extracted that form the basis for depicting the habitat preferences of the different species through an ordination diagram (ter Braak, and Verdonschot, 1995). The CCA is equivalent to weighted PCA as it can be applied in a matrix of species by environmental variables, with the species being given weight relative to their total abundance and the environmental variables being weighted inversely with their covariance matrix (ter Braak, 1987). In the ordination diagram (a biplot), the environmental variables are represented as arrows and the species as scattered points in the ordination space. The direction of maximum change of an environmental variable in respect to the ordination axes are specified by the points of the arrow, while the length of the arrow indicates the rate of change in the corresponding direction. The length of the arrow of an environmental variable is proportional to the strength of correlations with the ordination axes, and thus with the pattern of community variations shown in the ordination (ter Braak, 1987; ter Braak and Verdonschot, 1995). The direction of an environmental arrow can be viewed as axis allowing projection of the species points in order of the species rank in terms of weighted averages in context of that environmental variable (ter Braak, 1987). Based on the relative abundance, seven chironomid species and seven environmental variables (four original and three derived - N/P, N/C and P/C from the original values) were considered. This analysis was carried out to provide an explanation for the observed variations in the relative abundance of different species of chironomid using the environmental features as explanatory variables.

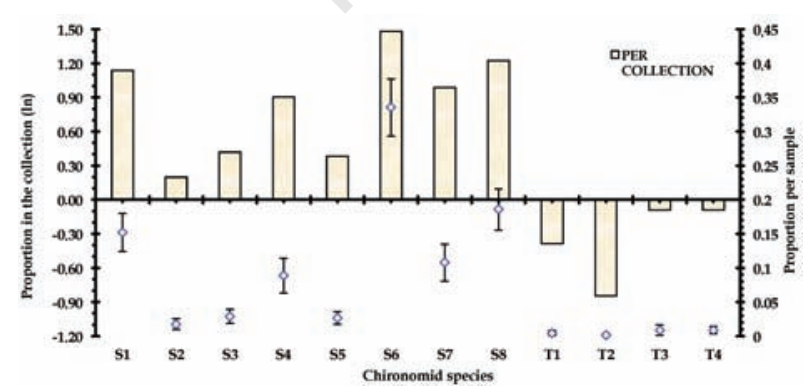

Fig 1. The proportion, based on relative abundance $\left(n \times m^{2}\right)$, of different chironomid species present in the total samples and in each sample from the ponds studied ( $\mathrm{n}=90$ samples) ( $\mathrm{S} 1-\mathrm{Ch}$ ronomus circumdatus, $\mathrm{S} 2$ - C. filitarsis, $\mathrm{S} 3$ - C. incertipennis, $\mathrm{S} 4$ - C. javanus, S5 - C. ramosus, S6- C. striatipennis, S7 - Kiefferulus barbatitarsis, S8 - K. calligaster, T1 - Tanypus bilobatus, T2 - T. grandis, T3 - T. lucidus and T4 - T. tenebrosus).
In order to judge the observed pattern of relative abundance of the chironomid species in the eight ponds, a Cluster Analysis (CA) based on Ward's method was carried out. It allowed interpreting the levels of similarity of the chironomid species in terms of their relative abundance. All the statistical analyses were carried out following Manly (1994), Zar (1999), and Legendre and Legendre (1998) using XL STAT software (Addinsoft, 2010) and SPSS ver 10 (Kinnear and Gray, 2000).

\section{RESULTS}

The number of chironomid species varied between 1 and 12 , depending on the ponds and sampling day. The most abundant species was Chironomus striatipennis followed by C. circumdatus, Kiefferulus calligaster and $K$. barbatitarsis. The predatory chironomid species Tanypus bilobatus, T. grandis, T. lucidus, and T. tenebrosus occurred rarely in the samples contributing to 10 individuals out of 2734 collected chironomid midges. The relative abundance of the chironomid species is presented as proportion frequency in Fig. 1 following transformation to natural logarthim $(\mathrm{ln})$ values. Owing to the least representation in the samples the predatory Tanypus species were not considered for further analysis. The values of the different water quality parameters of the water bodies including the nutrients are shown in Tab. 2. The values of nitrate, phosphate and carbon, reflect eutrophic conditions (Yang et al., 2008). The number of chironomid larvae per sample ranged between 1 and 90 (mean 30.38 $\pm 1.74 \mathrm{SE}$; variance, $s^{2}=270.64$ and variance to mean ratio: 8.91 ). The chironomid abundance was highest in the pond located in S1 $\left(n=562\right.$ chironomid larvae; $>40$ larvae $\left.\mathrm{m}^{-2}\right)$. The number of species recorded in all ponds varied too, with pond EII (eastern region) showing seven numbers of species in contrast to the pond NI where only two chironomid species

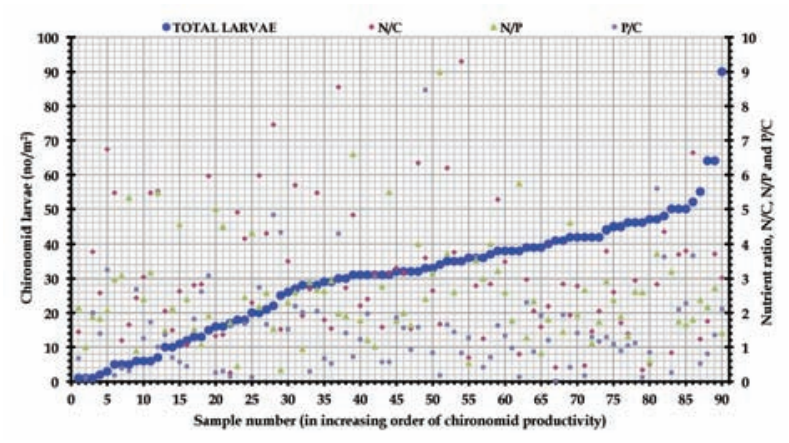

Fig. 2. The total number of chironomid larvae $\left(n \times m^{-2}\right)$ in the samples as a function of the N/P (nitrate: phosphate ratio), N/C (nitrate: carbon ratio) and $\mathrm{P} / \mathrm{C}$ (phosphate/ carbon ratio) $(\mathrm{n}=90$ samples from different ponds). 
were observed being the lowest in terms of diversity. The chironomid larval abundance against N/C, P/C and N/P ratio in each sample is shown in Fig. 2.

Based on the numbers of chironomid larvae collected per sample and the environmental (water quality parameters) variables (Tab. 2), the PCA shows that two factors, F1 and F2, explained more than $48 \%$ of the variation in the observed abundance of chironomid as a function of nutrients and environmental variables. The Kaiser-MeyerOlkin measure for sampling adequacy was 0.622. The Bartlett's Sphericity test showed significant value $\left(\chi^{2}=113.564 ; \mathrm{df}=28 ; \mathrm{P}<0.001\right)$ justifying sampling adequacy for application of application of PCA. The communalities of the variables considered were $>0.3$ with the

Tab. 3. The PCA of the dataset on the water quality parameters and number of chironomid larvae as obtained from the ponds in Kolkata ( $\mathrm{n}=90$ samples).

\begin{tabular}{|c|c|c|c|c|c|c|c|c|}
\hline \multicolumn{9}{|c|}{ A. Correlation matrix } \\
\hline \multicolumn{2}{|l|}{ Variables } & $\mathrm{N}$ & $\mathrm{K}$ & $\mathrm{P}$ & $\mathrm{C}$ & DO & $\mathrm{pH}$ & WT \\
\hline \multicolumn{2}{|l|}{ Potassium (K) } & $0.309^{*}$ & & & & & & \\
\hline \multicolumn{2}{|c|}{ Total phosphate $(\mathrm{P})$} & $0.599^{*}$ & $0.274^{*}$ & & & & & \\
\hline \multicolumn{2}{|c|}{ Organic carbon (C) } & $0.238^{*}$ & 0.001 & $0.287^{*}$ & & & & \\
\hline \multicolumn{2}{|c|}{ Dissolved oxygen (DO) (DO) } & 0.180 & 0.177 & -0.053 & -0.043 & & & \\
\hline \multicolumn{2}{|c|}{$\mathrm{pH}$} & $0.237^{*}$ & $0.278^{*}$ & $0.222^{*}$ & 0.137 & $0.400^{*}$ & & \\
\hline \multicolumn{2}{|c|}{ Water temperature (WT) } & 0.013 & 0.150 & -0.062 & -0.158 & $0.316^{*}$ & 0.078 & \\
\hline \multicolumn{2}{|c|}{ Total larvae (TL) } & 0.139 & 0.148 & 0.215 & $0.244^{*}$ & -0.046 & 0.173 & -0.137 \\
\hline \multicolumn{9}{|c|}{ "Values in italics indicate significance at $\mathrm{P}<0.05$ level. } \\
\hline \multicolumn{9}{|c|}{ B. Communalities and factor loadings. } \\
\hline Communalities & \multicolumn{3}{|l|}{ Variables } & \multicolumn{2}{|c|}{ F1 } & \multicolumn{2}{|l|}{ F2 } & F3 \\
\hline 0.59 & \multicolumn{3}{|l|}{$\mathrm{N}$} & \multicolumn{2}{|c|}{$0.764^{\circ}$} & \multicolumn{2}{|l|}{-0.071} & -0.377 \\
\hline 0.40 & \multicolumn{3}{|l|}{ K } & \multicolumn{2}{|c|}{$0.572^{\circ}$} & \multicolumn{2}{|l|}{0.266} & -0.217 \\
\hline 0.63 & \multicolumn{3}{|l|}{$\mathrm{P}$} & \multicolumn{2}{|c|}{$0.733^{\circ}$} & \multicolumn{2}{|l|}{-0.304} & -0.382 \\
\hline 0.40 & \multicolumn{3}{|l|}{$\mathrm{C}$} & \multicolumn{2}{|c|}{0.432} & \multicolumn{2}{|l|}{$-0.464^{\circ}$} & 0.304 \\
\hline 0.62 & \multicolumn{3}{|l|}{ DO } & \multicolumn{2}{|c|}{0.328} & \multicolumn{2}{|l|}{0.713} & 0.300 \\
\hline 0.47 & \multicolumn{3}{|l|}{$\mathrm{pH}$} & \multicolumn{2}{|c|}{$0.601^{\circ}$} & \multicolumn{2}{|l|}{0.331} & 0.448 \\
\hline 0.49 & \multicolumn{3}{|l|}{ WT } & & & $0.699^{\circ}$ & & -0.188 \\
\hline 0.35 & $\mathrm{TL}$ & & & & & -0.357 & & $0.490^{\circ}$ \\
\hline & Eigenvalue & & & & & 1.618 & & 1.005 \\
\hline & Variability (\%) & & & & & 20.219 & & 14.432 \\
\hline & Cumulative $\%$ & & & & & 48.740 & & 63.172 \\
\hline
\end{tabular}

${ }^{\circ}$ The highest loading of the variables for the factors are in italics.

C. The biplot showing the ordination of the variables.

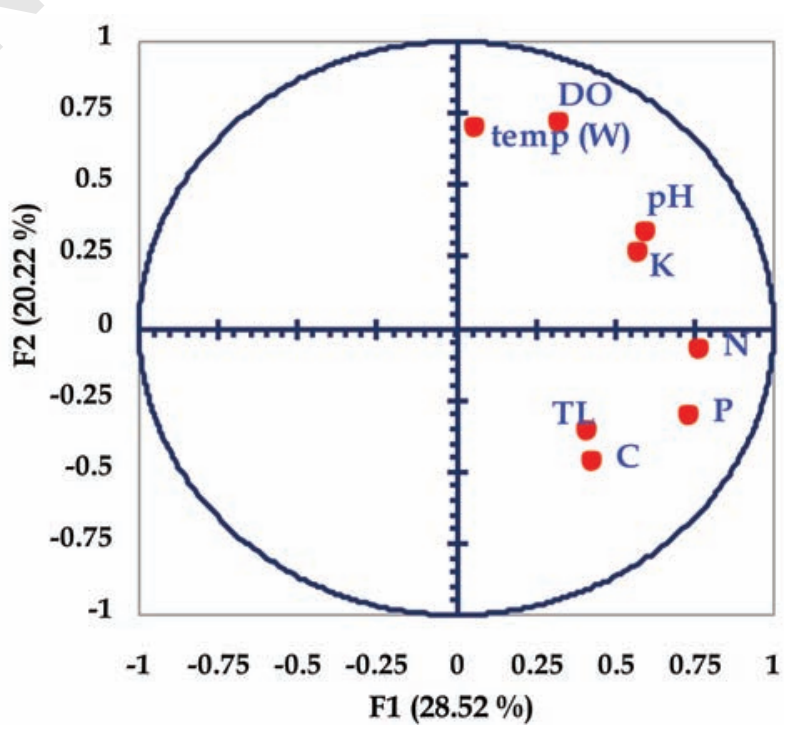


lowest value shown by the chironomid immature (total larvae). The ordination shows that a positive correlation exist between the nutrients and chironomid abundance while DO exhibited a negative correlation. The factor loadings and the contribution of the variables to the factors are shown in Tab. 3 .

The relation between total chironomid larvae per sampling unit with nitrate, phosphate, potassium and organic carbon (concentration) are shown in Fig. 3. The variations in the water bodies in terms of the chironomid larval abundance and the water quality were prominent. It appears from the bivariate regression equations, that abundance of chironomid larva depends on nitrate, phosphate, potassium and organic carbon (Fig. 3). The values of nitrate and potassium were log transformed that yielded a significant variance ratio ( $F$-value) for the regression equation though the $r^{2}$ values were low. Further analyses included all the environmental factors as explanatory variables for the observed differences in chironomid abundance.

The results of DCA revealed that the mean values were more than twice the standard deviations for the species and environmental axes and thus CCA application was justified. The four canonical axes explained $98 \%$ of variations in the species environment relation. The total inertia was 2.528 and the sum of all canonical eigenvalues was 0.224 . A test of significance of first canonical axis with eigen value 0.156 was significant at $\mathrm{P}<0.05$ level $(\mathrm{F}=5.126, \mathrm{P}=0.029)$. The first canonical eigenvalue $\left(\lambda_{1}=0.156\right)$ was 3.54 times the second one $\left(\lambda_{2}=0.044\right)$ indicating a clear gradient. The first two canonical axes explains $82.9 \%\left(\lambda_{1}=63.9 \%\right.$ and $\left.\lambda_{2}=19 \%\right)$ of variance in the weighted averages of the species with respect to each environmental variables. The ordination of the environmental and species variables is exhibited through the biplot (Fig. 4). From the length of the environmental arrows, it appears that temperature (E7) bear stronger correlation with the ordination axes while (E6) bear comparatively weaker correlation with the ordination axes. The species point projection along the direction (axis) of the environmental arrow indicates that $C$. filitarsis (S2) and $K$. calligaster (S8) occur in high temperature (E7) and potassium (E2) combination, while C. striatipennis (S6) occur in higher Nitrate: Phosphate ratio (N/P) and Nitrate: Carbon ratio (N/C), and C. circumdatus (S1) in higher Phosphate/ Carbon ratio $(\mathrm{P} / \mathrm{C})$. The environmental requirements of the species pairs, namely, C. filitarsis (S2) and C. javanus (S4), and C. ramosus (S5) and C. striatipennis (S6) appears to be highly contrasting. It is also apparent that the $\mathrm{pH}$ (E6) attributed weakly to the variations in the species abundance.

On the basis of the relative abundance per sample, CA (cluster analysis) allowed classification of the eight chironomid species under three central classes, as shown in Fig. 5. While C. filitarsis, C. incertipennis, C. ramosus
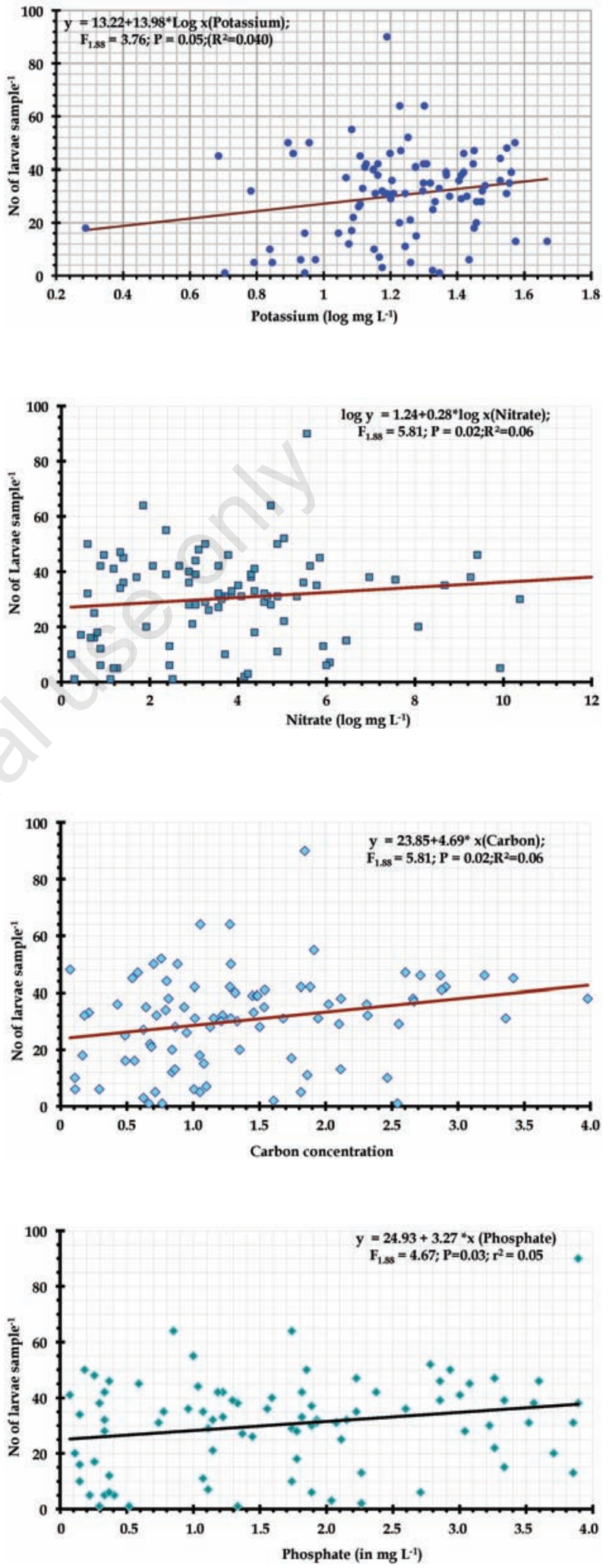

Fig. 3. Relations between chironomid productivity and the nutrients $\mathrm{K}$ (potassium), $\mathrm{N}$ (nitrate), $\mathrm{C}$ (organic carbon) and $\mathrm{P}$ (phosphate), along with the regression equations. Data were log transformed for potassium and nitrate. 
and $C$. striatipennis were under the same class and differed from C. circumdatus, $K$. barbatitarsis, and $K$. calligaster that belonged to another class. C. javanus was grouped under class number three. The CA reflects maximum similarity between the species $C$. filitarsis and $C$. striatipennis and maximum difference between C. striatipennis and $K$. calligaster based on Pearson correlation coefficient on the unweighted pair group average values.

\section{DISCUSSION}

From the present study, it is apparent that the abundance and richness of chironomid species vary with the nutrient conditions in the ponds, which is in parity with the earlier findings reported from different parts of the world, mainly in the lakes and streams of temperate zones. The diversity of chironomid in the wetlands and lotic habitats of West Bengal is high as evident from the studies on rice fields and riverine ecosystem (Guha et al., 1980; Chaudhuri et al., 1988, 1992; Chaudhuri and Chattopadhyay, 1990; Mazumdar et al., 2000). The species of chironomid midges observed in the present study are common in those habitats. However, the species richness in the ponds remained low in contrast to those habitats, which can be attributed to sampling bias, or due to the pollution and anthropogenic interferences. Low species richness of chironomid in artificial water bodies of urban areas have been recorded from South America than in rural areas (Hamerlík et al., 2011). Chironomid species such as $C$. striatipennis and C. circumdatus are common in both urban and rural areas (Guha et al., 1980; Chaudhuri et al., 1988; Al-Shami et al., 2010; Nandi et al., 2011). Their presence in those ecosystems provides a basis to consider these two species as indicator of the environmental states in both urban and rural context. For instance it has been proposed that certain species of midges can act as indicator of environmental conditions of inland lakes of Italy (Luoto, 2011). In view of this proposition and the observations of the present study, it would be pertinent to assess the effectiveness of individual chironomid species abundance as indicator of environmental condition of water bodies. The observed diversity of chironomid midges is comparatively low in contrast to the rice fields and wetlands in Southeast Asian countries (Guha et al., 1980; Al-Shami et al., 2010), primarily because of higher nutrient conditions. At a proximate level, the pond conditions show eutrophic state with positive correlations of nitrate against phosphate, organic carbon and potassium. The bivariate regression equations between individual nutrients and chironomid abundance showed a low $\mathrm{r}^{2}$ value, but highly significant $F$-values, perhaps owing to pond specific differences in the environmental conditions. It seems that the redundancy of the chironomid abundance and the nutrient states are not similar and thus could account for low $\mathrm{r}^{2}$ values of the linear regressions (Fig. 4).

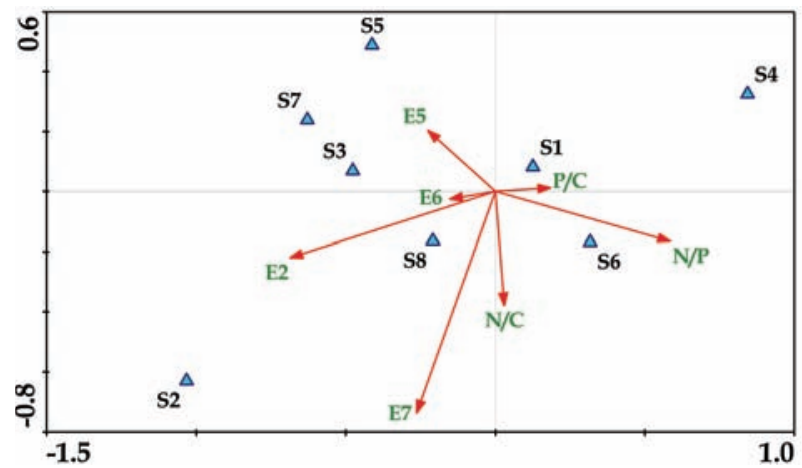

Fig. 4. Biplot of CCA showing the relationship of environmental factors and the chironomid species. [E2 (potassium), E5 (dissolved oxygen), E6 ( $\mathrm{pH})$, E7 (temperature), N/P (nitrate/phosphate ratio), N/C (nitrate/carbon ratio), $\mathrm{P} / \mathrm{C}$ (phosphate/carbon ratio), $\mathrm{S} 1$ (Chironomus circumdatus), $\mathrm{S} 2$ (C. filitarsis), S3 (C. incertipennis), S4 (C. javanus), S5 (C. ramosus), S6 (C. striatipennis), S7 (Kiefferulus barbatitarsis), S8 (K. calligaster)].

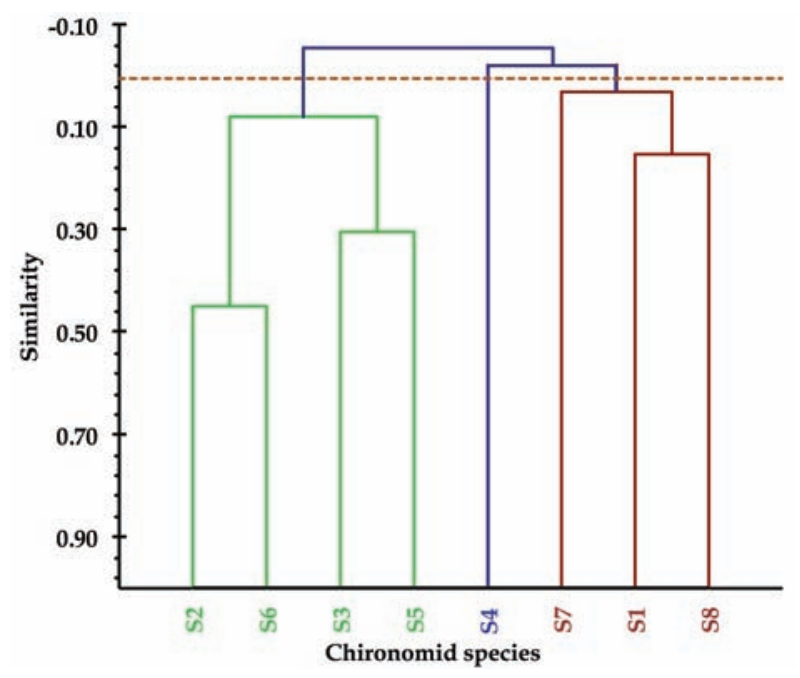

Fig. 5. Dendogram showing relationship among seven chironomid species based on their relative abundance in the samples. Colour of the lines represents classes (three clusters). The similarity is based on Pearson correlation coefficient and the classification is based on unweighted pair-group average (S1 Chironomus circumdatus, S2 - C. filitarsis, S3 - C. incertipennis, $\mathrm{S} 4$ - C. javanus, $\mathrm{S} 5$ - C. ramosus, $\mathrm{S} 6-C$. striatipennis, $\mathrm{S} 7$ - Kiefferulus barbatitarsis, S8 - K. calligaster). 
The significant $F$-values of the equations indicate that a change in chironomid abundance could be linked to corresponding changes in the individual nutrient states. This is substantiated by the observation that Chironomus spp. and Polypedilum spp. exhibit high abundance in lakes (Stevens et al., 2006) and rice fields (Al-Shami et al. 2010) contaminated with fertilizers and organic waste materials. The diversity of Chironomus spp. was high in the samples of the present study, possibly because of the eutrophic (Yang et al., 2008) condition of the ponds.

High chironomid species richness exists in a wide range of nutrient conditions (Rossaro, 1991; Lobinske et al., 1996; Ali et al., 2002, 2003; Stevens et al., 2006; Luoto, 2011). The richness of chironomid species are correlated with higher abundance than the co-occurring controphic and heterotrophic species in freshwater bodies (Rosenberg, 1992; Hasse and Nolte, 2008; Cushman et al., 2010). At a broader scale, fluctuations in the nutrient states and environmental parameters can be related to an equivalent change in chironomid species assemblage pattern as observed in different water bodies (Rossaro, 1991; Bazzanti et al., 1997; Rossaro et al., 2007; Tellioglu and Kara, 2009). Thus chironomid abundance can be used for monitoring the trophic conditions of the freshwater bodies. The results of the present study support this, since chironomid larval abundance exhibited correlated variations with the nutrients, dissolved oxygen, $\mathrm{pH}$ and temperature of the water bodies. This could possibly be a reflection of restricted fluctuation of the nutrient condition of the water bodies that lead to lower richness and abundance of chironomid midges. Tolerance to environmental conditions, particularly nutrient states, differs among chironomid species (Rosenberg, 1992; Luoto, 2011), and this can also be a plausible explanation for the low richness observed in the present study. The species composition was dominated by $C$. striatipennis, $C$. calligatser, $C$. javanus, $K$. calligaster, and $K$. barbatitarsis were dominant while Tanypodinae like Tanypus spp. was rare. This can be corroborated to trophic status of the ponds, since, Chironomus species dominate nutrient enriched anoxic condition (Saether, 1979; Rosenberg, 1992). Even though the ponds in the present context were nutrient enriched, nevertheless they are congenial habitat for at least twelve different chironomid species. Further studies on these ponds may provide evidence to select specific species for biomonitoring, since preference of environmental states vary for chironomid species and thus the effectiveness as bioindicator (Luoto, 2011). Nonetheless, considering the urban settings of Kolkata, India, chironomid abundance seems to be influenced by the nutrient states and various water quality parameters of the ponds. This provides an opportunity to develop and implement strategies for biomonitoring of urban ponds for ecological management including conservation policies.

\section{ACKNOWLEDGEMENTS}

The authors thankfully acknowledge the comments of three anonymous reviewers in modification of the earlier versions of the manuscript. The authors express gratitude to Prof. P.K. Chaudhuri, University of Burdwan, for the help rendered in identification of the chironomid species. The authors would also thank the respective Heads, Department of Zoology, University of Burdwan, and University of Calcutta, Kolkata, for the facilities provided included DST-FIST.

The financial assistance of UGC through the research projects (Sanction no. F No. 33-341/2007(SR) dt. 01.04.2008; GKS and SN) and (Sanction no. No. F. 3090 (SC)/2009 (SA II); 17.09.2009; GA) is acknowledged.

\section{REFERENCES}

Addinsoft SARL, 2010. XLSTAT software, version 10, Addinsoft, Paris, France.

Aditya G, Saha GK, 2006. Predation of the beetle Rhantus sikkimensis (Coleoptera, Dytiscidae) on the larvae of Chironomus Meigen (Diptera, Chironomidae) of the Darjeeling Himalayas of India. Limnologica 36:251-257.

Aditya G, Ash A, Saha GK, 2006. Predatory activity of Rhantus sikkimensis and larvae of Toxorhynchites splendens on mosquito larvae in Darjeeling, India. J. Vect. Borne Dis. 43: 6672.

Ali A, Frouz J, Lobinske RJ, 2002. Spatio-temporal effects of selected physico-chemical variables of water, algae and sediment chemistry on the larval community of nuisance Chironomidae (Diptera) in a natural and man-made lake in central Florida. Hydrobiologia 470: 181-193.

Ali A, Lobinske R, Frouz J, Leckel RJ, 2003. Spatial and temporal influence of environmental conditions on benthic macroinvertebrates in Northeast Lake Jesup, Central Florida. Florida Scient. 66: 69-83.

Al-Shami S, Che Salmah MR, Abu Hassan A, Siti Azizah MN, 2010. Temporal distribution of larval Chironomidae (Diptera) in experimental rice fields in Penang, Malaysia. J. Asia Pac. Entomol. 13: 17-22.

APHA (American Public Health Association, American Water Works Association and Water Pollution Control Federation), 1995. Standard Methods for the Examination of Water and Wastewater, $19^{\text {th }}$ ed. American Public Health Association, New York.

Ashe P, Cranston PS, 1990. Family Chironomidae. In: A. Soos and L. Papp (eds.), Catalogue of Palaearctic Diptera, Psychodidae-Chironomidae. Elsevier, Amsterdam/Academiai Kiado, Budapest, 2: 113-355.

Ashe P, Murray DA, Reiss F, 1987. The zoogeographical distribution of Chironomidae (Insecta: Diptera). Annal. Limnol. 23: 27-60.

Basu A, Ghosh K, Hazra N, Majumdar A, 2010a. Association of exoenzyme-producing bacteria with chironomid larvae (Diptera: Chironomidae) in relation to the feeding habit. Entomol. General. 32: 227-235.

Basu A, Hazra N, Ghosh K, 2010b. Bioindicator potentiality of the Chironominae larvae (Diptera: Chironomidae) for deter- 
mination of antibiotic resistant microbial load of the aquatic ecosystem. Proc. Zool. Soc. Kolkata 63:79-86.

Bazzanti M, Seminara M, Baldoni S, 1997. Chironomids (Diptera: Chironomidae) from three temporary ponds of different wet phase duration in Central Italy. J. Freshwat. Ecol. 12): 89-99.

Bhattacharyay G, Sadhu AK, Mazumdar A, Chaudhuri PK, 2005. Antennal deformities of chironomid larvae and their use in biomonitoring of heavy metal pollution in the River Damodar of West Bengal, India. Environ. Monitor. Assess. 108: 67-84.

Bhattacharyay G, Sadhu AK, Mazumdar A, Majumdar U, Chaudhuri PK, 2006. Assessment of impact of heavy metals on the communities and morphological deformities of chironomidae larvae in the river Damodar (India, West Bengal). Acta Hydrobiol. (Cracow) 8(Suppl.): 21-32.

Biswas JK, Rana S, Bhakta JN, Jana BB, 2009. Bioturbation potential of chironomid larvae for the sediment-water phosphorus exchange in simulated pond systems of varied nutrient enrichment. Ecol. Eng. 35: 1444-1453.

Carew ME, Pettigrove V, Cox RL, Hoffman AA, 2007. The response of Chironomidae to sediment pollution and other environmental characteristics in urban wetlands. Freshwat. Biol. 52: 2444-2462.

Chaudhuri PK, Chattopadhyay S, 1990. Chironomids of the rice paddy areas of West Bengal, India (Diptera: Chironomidae). Tijds. Entomol. 133: 149-195.

Chaudhuri PK, Das SK, Debnath RK, 1988. Studies of the Indian Tanypodinae (Diptera: Chironomidae), genus Tanypus Meigen. Polish J. Entomol. 55: 99-109.

Chaudhuri PK, Das SK, Sublette JE, 1992. Indian species of genus Chironomus Meigen (Diptera: Chironomidae). Zool. Jahrb. Syst. 119: 1-51.

Chaudhuri PK, Ghosh M, 1986. Two Indian species of Kiefferulus Goetghebuer (Diptera: Chironomidae). Systemat. Entomol. 11: 277-292.

Chaudhuri PK, Guha DK, 1987. A conspectus of Chironomid midges (Diptera: Chironomidae) of India and Bhutan. Entomol. Scand. (Suppl.) 29: 23-33.

Chaudhuri PK, Nandi SK, Ghosh M, 1983. Postembryonic stages of Tanypus bilobatus (Kieffer) n. comb. (Diptera: Chironomidae) with a note on its biology. Arch. Hydrobiol. 97: 122-133.

Cranston PS, Dillon ME, Pinder LCV, Reiss F, 1989. The adult males of Chironominae (Diptera: Chironomidae) of the Holarctic Region - keys and diagnoses. Entomol. Scand. Suppl. 34: 353-502.

Cranston PS, Hardy NB, Morse GE, 2012. A dated molecular phylogeny for the Chironomidae (Diptera). Syst. Entomol. 37: 172-188.

Cushman SA, Mckelvey KS, Noon BR, Mcgarigal K, 2010. Use of abundance of one species as a surrogate for abundance of others. Conser. Biol. 24: 830-840.

DeHaas EM, Wagner C, Koelmans AA, Kraak MHS, Admiraal W, 2006. Habitat selection by chironomid larvae, Fast growth requires fast food. J. Anim. Ecol. 75: 148-155.

Epler JH, 1992. Identification manual for the larval Chironomidae (Diptera) of Florida. State of Florida, Department of Environmental Protection, Tallahassee: 302 pp.

Epler JH, 1995. Identification manual for the larval Chironomi- dae (Diptera) of Florida. Final report for DEP Contract No.WM 579. State of Florida, Department of Environmental Protection, Tallahassee.

Epler JH, 2001. Identification manual for the larval Chironomidae (Diptera) of North and South Carolina. State of North Carolina, Department of Environment and Natural Resources, Raleigh: 526 pp.

Ferrington LC, 2008. Global diversity of non-biting midges (Chironomidae, Insecta-Diptera) in freshwater. Hydrobiologia 198: 447-455.

Guha DK, Chaudhuri PK, Nandi SK, 1980. Taxonomic studies of Chironominae (Chironomidae: Diptera) from West Bengal: Genus Dicrotendipes Kiefer. Proc. Zool. Soc. Calcutta (Kolkata) 33: 29-38.

Haase R, Nolte U, 2008. The invertebrate species index (ISI) for streams in southeast Queensland, Australia. Ecol. Indicat. 8: 599-613.

Hamerlík L, Jacobsen D, Brodersen KP, 2011. Low species richness of non-biting midges (Diptera: Chironomidae) in Neotropical artificial urban water bodies. Urban Ecosys. 14: 457-466.

Kinnear PR, Gray CD, 2000. SPSS for Windows made simple. Release $10.4^{\text {th }}$ ed. Psychology Press Ltd., East Sussex, UK: $432 \mathrm{pp}$.

Legendre P, Legendre L. 1998. Numerical ecology, $2^{\text {nd }}$ ed. Elsevier Science BV, Amsterdam, p. 853.

Lobinske RJ, Ali A, Stout J, 1996. Qualitative and quantitative studies on Chironomidae (Diptera) and selected physicochemical parameters in two tributaries of the Wekiva River, central Florida. Florida Entomol. 79: 531-542.

Luoto TP, 2011. The relationship between water quality and chironomid distribution in Finland - a new assemblage-based tool for assessments of long-term nutrient dynamics. Ecol. Indicat. 11: 255-262.

Manly BFJ. 1994. Multivariate Statistical Methods - A Primer, $2^{\text {nd }}$ ed. Chapman and Hall, London: $230 \mathrm{pp}$.

Manna B, Aditya G, Banerjee S, 2008. Vulnerability of the mosquito larvae to the guppies (Poecilia reticulata) in the presence of alternative preys. J. Vect. Borne Dis. 45: 200-206.

Manna B, Aditya G, Banerjee S, 2011. Habitat heterogeneity and prey selection of Aplocheilus panchax: an indigenous larvivorous fish. J. Vect. Borne Dis. 48:144-149.

Mazumdar A, Hazra N, Chaudhuri PK, 2000. New species of Cladotanytarsus Kieffer from the Deltaic region of West Bengal, India (Diptera: Chironomidae). Orient. Ins. 34: 193202.

Mousavi SK, 2002. Boreal chironomid community and their relations to environmental factors-the impact of lake depth, size and acidity. Boreal Environ. Res. 7: 63-75.

Nandi S, Aditya G, Saha GK, 2011. Life history study of Chironomus striatipennis Kieffer (Diptera: Chironomidae). Orient. Ins. 45: 186-193.

Ormerod SJ, Durance I, Terrier A, Swanson AM, 2009. Priority wetland invertebrates as conservation surrogates. Conserv. Biol. 24: 573-582.

Pinder LCV, 1978. A key to adult males of the British Chironomidae (Diptera). Sci. Publ. Freshwat. Biol. Assoc. 37: 1-169.

Robert V, Le Goff G, Ariey F, Duchemin B, 2002. A possible alternative method for collecting mosquito larvae in rice fields. Malaria J. 1:4. 
Rosenberg DM, 1992. Freshwater biomonitoring and chironomidae. Netherlands J. Aquat. Ecol. 26: 101-122.

Rossaro B, 1991. Factors that determine chironomidae species distribution in fresh waters. B. Zool. 58: 281-286.

Rossaro B, Marziali L, Cardoso AC, Solimini A, Free G, Giacchini R, 2007. A biotic index using benthic macroinvertebrates for Italian lakes. Ecol. Indicat. 7: 412-429.

Saether O, 1979. Chironomid communities as water quality indicators. Holarctic Ecol. 2: 65- 74.

Saha N, Aditya G, Saha GK, 2009. Habitat complexity reduces prey vulnerability: an experimental analysis using aquatic insect predators and immature dipteran prey. J. Asia Pac. Entomol. 12: 233-239.

Saha N, Aditya G, Saha GK, Hampton SE, 2010. Opportunistic foraging by heteropteran mosquito predators. Aquat. Ecol. 44: 167-176.

Stevens M, Helliwell S, Cranston PS, 2006. Larval chironomid communities (Diptera: Chironomidae) associated with establishing rice crops in New Southern Wales, Australia. Hydrobiologia 556: 317-325.
Tellioglu A, Kara T, 2009. Seasonal abundance of Chironomidae Larvae (Diptera) in Büyük Stream, Elazğ, Turkey. J. Freshwat. Ecol. 24: 169-171.

ter Braak CJF, 1987. The analysis of vegetation-environment relationships by canonical correspondence analysis. Vegetatio 69: 69-77.

ter Braak CFJ, Šmilauer P, 2002. CANOCO reference manual and canodraw for windows user's guide: software for canonical community ordination (version 4.5). Ithaca, NY, USA (www.canoco.com): Microcomputer Power CANOCO for Windows version 4.5.

ter Braak CFJ, Verdonschot PEM, 1995. Canonical correspondence analysis and related multivariate methods in aquatic ecology. Aquat. Sci. 57: 255-289.

Yang X-E, Wu X, Hao H-L, He Z-L, 2008. Mechanisms and assessment of water eutrophication. J. Zhejiang Univ. Sc. B. 9:197-209.

Zar JH, 1999. Biostatistical Analysis. $4^{\text {th }}$ ed. Pearson Education (Singapore) Pte. Ltd., New Delhi: 663 pp. 